\title{
ILMU MENDIDIK TEORETIS: BIJAK DALAM BERMEDIA SOSIAL
}

\author{
R. Dandy Jurindra Pratama ${ }^{1}$ \\ Bustomi Arifin ${ }^{2}$ \\ ${ }^{1}$ Fakultas Teknik, Universitas Narotama, Surabaya \\ ${ }^{2}$ Fakultas Keguruan dan Ilmu Pendidikan, Universitas Narotama Surabaya \\ mek.dandy@gmail.com
}

\begin{abstract}
Abstrak
Media sosial dewasa ini merupakan sebuah media yang banyak akses oleh hampir seluruh lapisan masyarakat di Indonesia. Hal ini dikarenakan hampir seluruh lapisan masyarakat dapat dengan mudah mengakses media sosial. Kemudahan dalam bermedia sosial membuat seluruh kalangan masyarakat Indonesia mudah menerima informasi dari seluruh penjuru Indonesia maupun dunia. Kemudahan dalam mengakses media sosial dan terbuka nya pintu infomasi melalu media sosial mendorong lahir nya oknum-oknum yang tidak bertanggung jawab dengan menyebarkan berita atau informasi yang tidak sesuai dengan realita atau kenyataan yang ada atau disebut dengan hoaks. Isu tersebut semakin berkembang dengan pesat dikalangan masyarakat Indonesia mengingat minim nya sikap selektif serta kritis dari masyarakat Indonesia dalam menerima informasi yang terdapat pada media sosial. Dampak negatif yang ditenggarai dapat muncul terkait sikap selektif dan kritis dalam menerima informasi pada media sosial adalah lunturnya nilai-nilai ketahanan nasional. Isu tersebut diatas menjadi dasar acuan bagi penulis dalam menyusun jurnal ini. Jurnal ini menggunakan metode deksriptif analisis dengan menggunakan pemahaman yang dicetuskan oleh Prof. Driyakarna yaitu ilmu mendidik teoretis. Jurnal ini diharapkan mampu mendorong masyarakat Indonesia agar lebih selektif dan kritis terhadap informasi yang tersebar diberbagai media sosial.
\end{abstract}

Kata kunci: Media Sosial, Masyarakat Indonesia, Selektif, Ilmu Mendidik Teoretis 


\begin{abstract}
Social media today is a medium that many access by almost all levels of society in Indonesia. This is because almost all levels of society can easily access social media. Ease in social media makes all the people of Indonesia easy to receive information from all over Indonesia and the world. Ease in accessing social media and the opening of information gates through social media encourages the birth of irresponsible elements by disseminating information that is inconsistent with the reality. The issue is growing rapidly among the people of Indonesia, it is given the lack of selective and critical attitude of the people of Indonesia in receiving information contained in social media. Negative impacts that may arise may arise related to selective and critical attitude in receiving information on social media is the diminution of national resilience values. The above issues become the basis of reference for authors in compiling this article. It uses the descriptive method of analysis by using an understanding that Prof. Driyakarna is theoretical educational science. It is expected to encourage Indonesian people to be more selective and critical of information spread across various social media.
\end{abstract}

Key Terms: Social Media, Indonesian Society, Selective, Theoretical Educational Science

\title{
PENDAHULUAN
}

Era globalisasi telah mengakrabkan kita dengan internet. "Internet adalah kumpulan atau jaringan dari jaringan komputer yang ada di seluruh dunia. Dalam hal ini komputer yang sebelumnya stand-alone kini dapat berhubungan langsung dengan host-host atau komputer-komputer lain. Internet sebenarnya mengacu kepada istilah untuk menyebut sebuah jaringan, bukannya suatu aplikasi tertentu. Oleh karenanya, internet tidaklah bermanfaat tanpa adanya aplikasi yang sesuai." (J. Sinarmata, 2006 : 281). Seperti halnya telpon, internet pun adalah hal serupa. Hanya sebuah media penghubung. Jika telpon hanya dapat menghubungkan media berupa suara, lain halnya dengan internet, yang dapat menghubungkan hampir semua media, baik berupa suara, gambar, bahkan berupa video. Dan internet tidak akan bisa bermanfaat jika tidak adanya aplikasi. Aplikasi yang dimaksud salah satunya adalah berupa media sosial. 
Media dimana banyak orang dapat terhubung. Baik orang yang dikenal, maupun orang yang tidak kita kenal sama sekali, dapat terhubung satu sama lain. Media dimana orang dapat berkenalan satu sama lain, walaupun sebelumnya mereka tidak saling mengatahui satu sama lain. Dan juga media dimana kita dapat membagi segala aktivitas yang kita lakukan, baik aktivitas positif maupun aktivitas negatif. Karena kebebasan berinteraksi dan kebebasan membagi segala aktivitas ini lah, dapat menyebabkan berbagai aliran maupun kepentingan yang saling bertolak belakang dapat bertemu, bahkan sangat dikhawatirkan dapat berbenturan satu sama lain. Bahkan, bukan tidak mungkin, beberapa golongan akan mempengaruhi golongan lain. Hal ini lah yang sangat dikhawatirkan, baik sebagai individu, maupun sebagai negara.

Bukan tidak mungkin, paham-paham yang bertentangan dengan negara Indonesia akan mulai menyusup masuk, satu persatu. Sedikit demi sedikit kemudian berkembang, dari sekelompok minoritas dan akan berkembang menjadi mayoritas. Dari yang berawal sembunyi-sembunyi hingga bergerak secara terang-terangan. Jika sudah menjadi besar, maka negara pun akan sulit untuk meredamnya. Hal ini lah yang akan memicu kegoyahan stabilitas ketahanan nasional. Akan ada pihak yang membela negara dan akan ada pihak yang menginginkan sebuah negara merdeka dibawah paham yang mereka anut. Jika hal tersebut tidak segera diredam dan dihilangkan, bukan tidak mungkin, kelak akan terjadi sebuah perang dalam negeri, atau dengan kata lain perang saudara yang dapat mengancam keutuhan NKRI.

\section{PEMBAHASAN}

Pada tahun 2017 Indonesia sempat dihebohkan dengan kasus penangkapan sindikat yang menyebarkan berita palsu alias hoax. Sindikat tersebut dibayar dari puluhan juta hingga ratusan juta rupiah untuk membuat dan menyebarkan berita palsu. Mulai dari berita yang berisi informasi ringan hingga berita politik yang sangat mempengaruhi jalannya proses pemilihan di beberapa tempat kala itu. Sampai saat ini anggota sindikat tersebut masih belum tuntas dibasmi. Tidak sedikit masyarakat yang menerima dan mempercayai informasi yang disebarkan oleh sindikat tersebut dalam media sosial. Dampak negatif yang mungkin dapat timbul dan akan sangat merugikan adalah ketika media internet akan menjadi sebuah trend tersendiri 
khususnya pada hal-hal yang ditujukan untuk berpolitik saat pemilu datang. (Lukis Alam, 2009 : 8)

Media sosial memiliki salah satu dampak negatif yaitu akan mengurangi kepekaan penggunanya. Kekurangpekaan terhadap dirinya sendiri, maupun kekurangpekaan terhadap sekitar. Hal ini tampak dari hasil penelitian yang dilakukan oleh Ningrum dimana kepekaan sosial peserta didik SLTPN 1 Demak terlihat rendah pada saat mereka menggunakan media sosial (facebook) dalam memberikan penilaian negatif terhadap teman dengan menggunakan kata-kata kurang sopan. Namun disisi lain kepekaan sosial para peserta didik tersebut meningkat ketika ada teman yang menginformasikan tentang berita duka maupun gembira yang mana berita tersebut menuntut para teman dalam dunia maya untuk saling peka dan peduli terhadap sesama (Dwi Indah Mustiko Ningrum, 2015 : 101).

Hal tersebut lah yang memicu terjadinya keegoisan diri sendiri. Keegoisan memaksakan semua paham haruslah sesuai dengan keinginannya. Berawal dari hal tersebut lah kemudian lahir kelompok-kelompok ekstrim. Kelompok yang selalu memaksakan kehendaknya sendiri. Dan jika negara tidak sepemahaman dengan mereka, mereka tidak segan untuk melawan negara, bahkan mereka tidak segan untuk menghancurkan negara yang melawan mereka. "Data di atas memperlihatkan bahwa gerakan komunitas memiliki kekuatan yang besar dalam membangun ketahanan informasi nasional di Indonesia, khususnya untuk menyikapi berbagai informasi dan berita bohong atau hoax semata." (Ditha Prasanti dkk, 2017 : 17).

"Beberapa negara sudah memiliki unit khusus pasukan siber dalam pertahanan dan keamanan negaranya. Badan ataupun organisasi tersebut bertugas menghimpun segala usaha pertahanan dan serangan balik terhadap keamanan di dunia siber beserta sistem jaringannya. Melihat kekuatan dan ancaman yang dapat terjadi akibat kemajuan teknologi informasi, banyak negara mulai membangun kekuatan angkatan perang siber. Sebab perang ini bukan lagi sekadar game virtual dan cerita fiksi, tapi sudah menjadi bagian dari percaturan dunia." (Bagus Artiadi Soewardi, 33). Negara Indonesia sudah memiliki badan pertahanan keamanan dunia maya yang bertugas untuk melindungi serangan dari dunia maya, baik dari luar negeri, maupun dari dalam negeri itu sendiri. Baik berupa serangan frontal, maupun serangan yang 
tersembunyi. Keberadaan badan pertahanan keamanan dunia maya tidak dapat berjalan dengan maksimal tanpa adanya dukungan dari seluruh lapisan masyarakat yang mengakses informasi melalui media sosial. Adapun dukungan dari masyarakat yang sangat dibutuhkan dalam memberantas informasi hoaks pada media sosial adalah dengan bersifat kritis dan selektif dalam membaca dan menanggapi informasi yang beredar dalam media sosial. Maraknya penggunaan media sosial pada berbagai kalangan masyarakat di Indonesia serta banyaknya berita hoaks yang tersebar menuntut seluruh kalangan masyarakat untuk lebih bersifat kritis dan selektif dalam menanggapi informasi yang beredar pada media sosial. Adapun kalangan masyarakat yang dimaksud adalah elemen masyarakat secara keseluruhan dan masyarakat dalam dunia pendidikan (guru, dosen dan peserta didik disemua tingkat). Peningkatan sifat kritis dan selektif pada seluruh elemen masyarakat dapat dilakukan melalui pendidikan baik yang bersifat formal, informal dan nonformal.

Pendidikan formal, informal maupun non-formal memiliki peran yang besar dalam mencetak masyarakat yang kritis dan selektif dalam menyaring informasi yang beredar pada media sosial. Hal ini seiring dengan apa yang disampaikan oleh Prof. Driyakarna dimana pendidikan hendaknya mampu menciptakan budaya pemikiran yang kritis, metodis dan sistematis (Sudiarja, A. Dkk, 2006). Kritis dalam artian tidak hanya menerima apa yang ditangkap dalam benaknya namun semua afirmasi harus memiliki dasar yang cukup. Budaya pemikiran kritis terkait maraknya informasi hoaks dalam media sosial adalah seluruh elemen masyarakat hendaknya memiliki sikap kritis yang mana seluruh elemen masyarakat ketika menerima atau mengakses informasi melalui media sosial tidak sekedar menerima apa yang ditangkap dalam benaknya. Masyarakat juga perlu untuk melakukan proses afirmasi yang harus disertai dengan dasar yang kuat serta logis. Metodis dalam artian bahwa dalam proses berpikir dan menyelidiki, seseorang harus menggunakan sebuah cara tertentu yang dapat dipertanggung jawabkan secara logika. Budaya pemikiran metodis terkait maraknya informasi hoaks dalam media sosial adalah masyarakat hendaknya menggunakan sebuah metode dalam menelaah seluruh informasi yang terdapat pada media sosial. Metode yang digunakan pun hendaknya dapat dipertanggung jawabkan secara logis guna memperoleh 
kebenaran dari informasi yang beredar pada media sosial. Sistematis dalam artian seseorang dalam berpikir dan menyelidiki membutuhkan adanya sebuah kesatuan ide meyeluruh dari berbagai macam informasi. Budaya pemikiran sistematis yang berarti masyarakat dalam berpikir dan menyelidiki informasi yang ada pada media sosial hendaknya melakukan penggabungan ide-ide teratur menurut sistem yang berlaku di Indonesia. Budaya pemikiran ini bertujuan agar masyarakat memiliki sebuah cara yang diatur dengan baik dalam berpikir dan menyelidiki informasi yang beredar dimedia sosial.

Pendidikan terbukti memiliki hubungan yang kuat dan positif terhadap ketahanan individu, artinya semakin tinggi budaya pendidikan maka semakin tinggi pula ketahanan individu. Apabila dibandingkan antara nilai-nilai budaya generasi millennial dan budaya pendidikan maka dapat diketahui bahwa budaya pendidikan memiliki hubungan atau korelasi yang lebih kuat terhadap ketahanan individu (Heru Dwi Wahana, 2015 : 6).

\section{KESIMPULAN}

Berdasarkan penjelasan tersebut diatas maka dapat disimpulkan bahwa dukungan dari seluruh lapisan masyarakat dalam meminimalisir informasi pada media sosial memegang peranan penting. Badan Pertahanan Keamanan Dunia Maya tidak dapat bekerja secara maksimal tanpa dukungan dari seluruh lapisan masyarakat Indonesia. Dukungan dari seluruh lapisan masyarakat dapat berupa sikap kritis dan selektif dalam menerima dan menyebarkan informasi pada media sosial. Selain itu, budaya pemikiran yang kritis, metodis dan sistematis trekait informasi pada media sosial dinilai mampu mengeliminasi penyebaran berita hoaks pada media sosial. Dengan kata lain sikap pemikiran yang kritis, metodis dan sistematis dalam bermedia sosial dapat mencegah adanya potensi atau gejala-gejala yang menimbulkan keresahan dimasyarakat yang mana potensi maupun gejala-gejala tersebut dapat mengancam persatuan dan ketahanan nasional. Berita negatif yang tidak benar dapat menimbulkan kebingungan dimasyarakat serta keresahan.(Abdul Haris Subarjo, $2017: 5$ ). 


\section{DAFTAR PUSTAKA}

Alam, Lukis. 2009. Influinsasi Media Internet Terhadap Proses Pemilu Di Indonesia. Yogyakarta : UPN "Veteran"

Haris Subarjo, Abdul. 2017. Literasi Masyarakat Terhadap Penyebaran BeritaBerita Viral Internet Dan Hubungannya Dengan Ketahanan Nasional. Yogyakarta : Sekolah Tinggi Teknik Adisutjipto

Ningrum, Dwi Indah Mustiko. 2015. Dampak Penggunaan Facebook Terhadap Kepekaan Sosial Peserta Didik Di Smp Negeri 1 Demak. Semarang : Universitas Negeri Semarang

Prasanti, Ditha \& Dinda Rakhma Fitriani. 2017. Membangun Ketahanan Informasi Nasional Dalam Komunikasi Kesehatan Bagi Kalangan Perempuan Urban Di Jakarta.

Sudiarjia, A. Dkk, 2006, Karya Lengkap Driyakara: Esai-Esai Filsafat Pemikiran yang Terlibat Penuh dalam Perjuangan Bangsanya, PT. Gramedia Pustaka Utama, Jakarta.

Soewardi, Bagus Artiadi. 2013. Perlunya Pembangunan Sistem Pertahanan Siber (Cyber Defense) yang tangguh bagi Indonesia. Media Informasi Ditjen Pothan Kemhan

Wahana, Heru Dwi. 2015. Pengaruh Nilai-Nilai Budaya Generasi Millennial Dan Budaya Sekolah Terhadap Ketahanan Individu. Jakarta 